\title{
Rates and sources of nitrogen fertilizer application on yield and quality of Panicum maximum cv. Mombasa
}

\author{
Efecto de dosis y forma de aplicación de fertilizante nitrogenado \\ en el rendimiento y calidad de Panicum maximum $c v$. Mombasa \\ Fernando Shintate Galindo ${ }^{*}$, Salatiér Buzetti ${ }^{1}$, \\ Marcelo Carvalho Minhoto Teixeira Filho ${ }^{1}$, Elisângela Dupas ${ }^{1}$
}

\begin{abstract}
The effects of nitrogen fertilizer sources (urea and ammonium nitrate) applied at different rates on the yield and quality of Megathyrsus maximus $c v$. Mombasa were compared in this study. The nitrogen rates applied after each monthly harvest were $0,50,100,150$ and $200 \mathrm{~kg} \mathrm{~N} / \mathrm{ha}$ (i.e., 0, 150, 300, 450 and $600 \mathrm{~kg} \mathrm{~N} / \mathrm{ha} / \mathrm{year}$ ). The $\mathrm{N}$ fertilizer sources did not affect the Mombasa grass response to any of the production and nutritional characteristics; however, increasing nitrogen rates there was significantly increased dry matter yield and crude protein percentage, and decreased neutral detergent fiber (NDF) concentrations. Dry matter yield in control treatments was $31.3 \mathrm{t} / \mathrm{ha}$, and responses reached a maximum of $30 \%$ with the application of $150 \mathrm{~kg} \mathrm{~N} / \mathrm{ha} / \mathrm{cut}$, but considering the economical rate, the better economic return occurs with the application of $115 \mathrm{~kg} \mathrm{~N} / \mathrm{ha} / \mathrm{cut}$. As urea has a lower price per unit of $\mathrm{N}$ than ammonium nitrate, it seems to be the best choice of fertilizer. Further studies are needed to determine why the dry matter yields of forage were so high and in what seasons should $\mathrm{N}$ fertilizer be applied when resources are limited. Longer-term studies would confirm these findings and assess the losses of $\mathrm{N}$ to the atmosphere or by leaching, especially at the higher rates.
\end{abstract}

Key words: Ammonium nitrate, crude protein, fertilizer responses, guinea grass, urea.

\section{RESUMEN}

Este estudio comparó los efectos de las formas de fertilizante nitrogenado (urea y nitrato de amonio) a tasas variables en el rendimiento y la calidad de Megathyrsus maximus cv. Mombasa. Las tasas de nitrógeno fueron 0, 50, 100, 150 y $200 \mathrm{~kg} \mathrm{~N} / \mathrm{ha}$ después de cada cosecha mensual, es decir, 0, 150,300, 450 y $600 \mathrm{~kg} \mathrm{~N} / \mathrm{ha} /$ temporada. La forma de fertilizante N no afectó las respuestas en ningún parámetro, pero el aumento de las tasas de nitrógeno aumentó significativamente el rendimiento de materia seca y el porcentaje de proteína bruta, y disminuyó las concentraciones de FDN. Los rendimientos de materia seca en los tratamientos de control fueron de 31,3 t DM / ha y las respuestas alcanzaron un máximo del 30\% con una aplicación de $150 \mathrm{~kg} \mathrm{N/ha}$ I mes, pero en vista de la tasa económica, el mejor retorno económico se produce con la aplicación de $115 \mathrm{~kg} \mathrm{~N} / \mathrm{ha} / \mathrm{mes}$. Como la urea es más barata por unidad de $N$ que el nitrato de amonio, parece ser el fertilizante de elección. Se necesitan más estudios para determinar por qué los rendimientos básicos de forraje fueron tan altos y en qué estaciones se debe aplicar fertilizante con $N$ cuando los recursos son limitados. Los estudios a más largo plazo confirmarían estos hallazgos y evaluarían las pérdidas de $N$ en la atmósfera y mediante la lixiviación, especialmente en las tasas más altas.

Palabras clave: nitrato de amonio, proteína bruta, respuestas de fertilizantes, capim mombasa, urea.

\section{Introduction}

Brazil has about 180 million hectares of pastures and is one of the largest commercial cattle producers of the world, which depend on pastures as their main feed source (Galindo et al. 2018) since they are less costly than other forms of feed (Fernandes et al. 2015). However, pastures are generally not fertilized and, over time, quality and production decline, leading to pasture degradation (Galindo et al. 2017).

While many grass species are grown in Brazil, Mombasa guinea grass (Megathyrsus maximus) is widely cultivated for grazing by cattle. In subtropical

\footnotetext{
1 Department of Plant Health, Rural Engineering and Soils, Faculdade de Engenharia de Ilha Solteira, Universidade Estadual Paulista "Júlio de Mesquita Filho". Ilha Solteira, Sao Paulo State, Brazil.

* Corresponding author: fs.galindo@yahoo.com.br
}

Fecha de Recepción: 07 Febrero, 2019.

Fecha de Aceptación: 04 Mayo, 2019. 
and tropical environments, this grass can have an annual dry matter yield up to $33 \mathrm{t} / \mathrm{h}$ a with nitrogen fertilizer management (Galindo et al. 2017). However, proper management of soil fertility and knowledge of the nutritional requirements of this grass are extremely important to maintain this high production (Fernandes et al. 2015).

The most commonly used nitrogen $(\mathrm{N})$ fertilizer in Brazil is urea, mainly because it has a high concentration of $\mathrm{N}$ and has a lower cost per unit of $\mathrm{N}$ when compared with other nitrogen fertilizer sources. However, the $\mathrm{N}$ losses from urea through volatilization of ammonia $\left(\mathrm{NH}_{3}\right)$ can be high, so some farmers use other sources of nitrogen fertilizers, such as ammonium nitrate, which consists of $50 \% \mathrm{~N}^{-\mathrm{NH}_{4}}{ }^{+}$

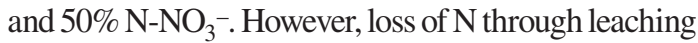

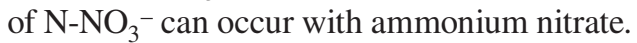

Silveira et al. (2015) studied the effects of $\mathrm{N}$ rates $(0,60$ and $120 \mathrm{~kg} \mathrm{~N} /$ ha/year) and different $\mathrm{N}$ fertilizer sources (ammonium nitrate, ammonium sulfate, urea, Agrotain ${ }^{\circledR}$ treated with urea, urea with urease inhibitor and ammonium sulfate nitrate) on Bahiagrass (Paspalum notatum) response, and showed that dry matter yield (DMY) increased linearly with increasing $\mathrm{N}$ rates for all treatments, with the only difference between fertilizer sources being a reduced response with ammonium nitrate in the second year of the study. Similarly, Benett et al. (2008) found that increasing $\mathrm{N}$ rates $(0,50,100,150$ and $200 \mathrm{~kg} \mathrm{~N} / \mathrm{ha} /$ cut) significantly increased DMY in Marandu palisade grass (Urochloa brizantha cv. Marandu) with linear response throughout and no difference between ammonium sulfate nitrate, ammonium sulfate, and urea.

The objectives of this trial were to study the effects of $\mathrm{N}$ fertilizer sources (urea or ammonium nitrate) applied at different rates after each growing season on dry matter yield and chemical composition of Mombasa guinea grass grown in the Brazilian Cerrado region.

\section{Material and Methods}

The experiment was conducted in Ilha Solteira - São Paulo State, Brazil ( $20^{\circ} 21^{\prime}$ S, $51^{\circ} 22^{\prime}$ W; and altitude of $326 \mathrm{~m}$ a.s.1.). The Mombasa guinea grass pasture was established in 2006 and grazed for 6 years until starting this trial, which occurred in November 2012. The soil was classified as a sandy Arenic Hapludult or Ultisol (Embrapa 2013). Before starting the trial, the soil was sampled from $0-20$ $\mathrm{cm}$ layer and main chemical properties were as follows: $\mathrm{P}$ resin $=13 \mathrm{mg} / \mathrm{dm}^{3} ; \mathrm{pH}$ in $\mathrm{CaCl}_{2}=5.2$; $\mathrm{K}^{+}=2.2, \mathrm{Ca}^{2+}=35.0, \mathrm{Mg}^{2+}=7.0, \mathrm{H}^{+}+\mathrm{Al}^{3+}=16.0$, $\mathrm{SB}=44.2, \mathrm{CEC}=60.2 \mathrm{mmol}_{\mathrm{c}} / \mathrm{dm}^{3}$, respectively; organic matter $(\mathrm{OM})=25 \mathrm{~g} / \mathrm{dm}^{3}$; and soil base saturation $(\mathrm{V})=73 \%$.

Total rainfall, minimum, average and maximum temperature, global and liquid radiation during the trial are shown in Figure 1. According to Koppen, the regional climate type is Aw, described as the humid tropical climate with hot and wet summers, and dry winters, with a dry season between May and September.

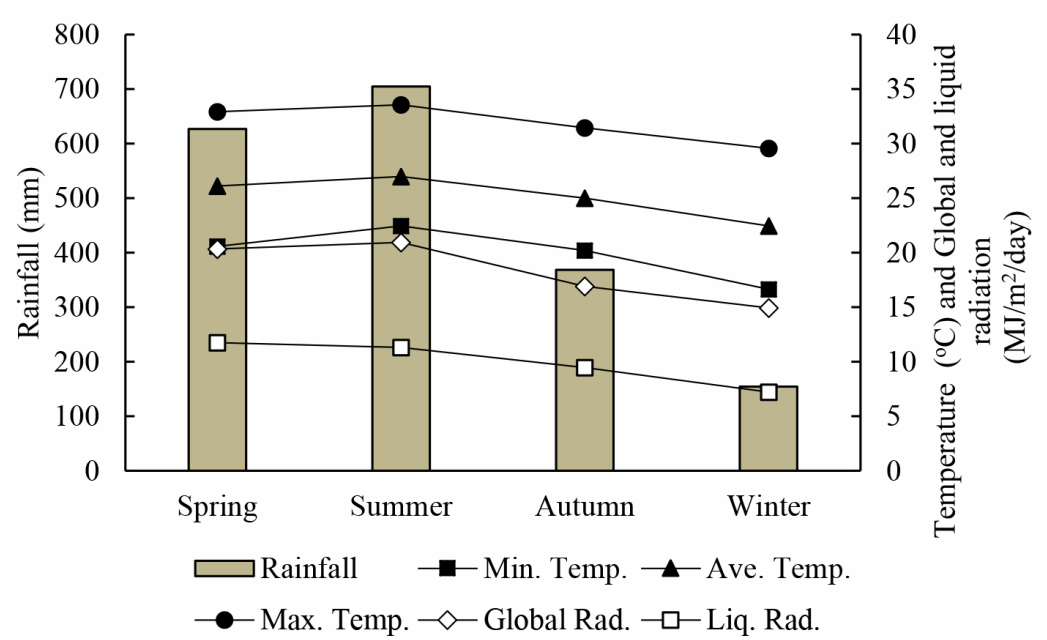

Figure 1. Climate data obtained from the weather station located at the study site in Ilha Solteira - SP for intervals between seasons. Period: December 2012-January 2014. 
The trial was arranged in a randomized block design with four replicates. The treatments consisted of two $\mathrm{N}$-fertilizer sources [urea $(45 \% \mathrm{~N})$ or ammonium nitrate $(32 \% \mathrm{~N})$ ] and five $\mathrm{N}$ rates $(0$, $50,100,150$ and $200 \mathrm{~kg} \mathrm{~N} /$ ha/cut), applied monthly after each harvest of the Mombasa guinea grass, totaling the following season rates of $0,150,300$, 450 and $600 \mathrm{~kg} \mathrm{~N} / \mathrm{ha} / \mathrm{year}$. The fertilizers were manually applied in topdressing on the pasture and were not watered after application, simulating the standard practice for fertilization of conventional pastures in Brazil. The plots consisted of $6.0 \mathrm{~m}^{2}$ $(3 \times 2 \mathrm{~m})$ with $2.0 \mathrm{~m}$ spacing between plots.

The Mombasa guinea grass was initially cut to $25 \mathrm{~cm}$ above ground level on November 2012, when the study started, and harvests were made monthly at the same cut level from December 2012 to January 2014.

Pasture yield data were bulked according to seasons/time of the year when pasture had grown, i.e. resulting up to the following harvests: spring (December 2012; November and December 2013); summer (January and February 2013; January 2014); autumn (March, April and May 2013); and winter (June, August and September 2013). After every three harvests, i.e., quarterly, $60 \mathrm{~kg} \mathrm{~K}_{2} \mathrm{O} / \mathrm{ha}$ was applied. Following harvesting fresh forage yields were determined in the field and representative samples were taken and dried in an oven at $55^{\circ} \mathrm{C}$ for three days, for determination of dry matter yield (DMY). Further samples were taken for chemical analyses.

For determination of neutral detergent fiber (NDF), acid detergent fiber (ADF), lignin, cellulose, and hemicellulose the methodologies proposed by Casali et al. (2009) and van Soest (1994) were used. Total nitrogen concentration (TN) was determined by the semi-micro Kjeldahl method, and protein concentration (CP) was calculated by multiplying the $\mathrm{N}$ concentration by 6.25 .

Data from the trial were submitted to analysis of variance (F test) using the SISVAR program (Ferreira 2011). For N sources, the Tukey test was used to compare the means, whereas regression analysis was used for the $\mathrm{N}$ fertilizer rates and significant equations (F-test, $\mathrm{p} \leq 0.05$ ) with the highest coefficients of determination were adjusted.

\section{Results and Discussion}

The spring, summer, autumn and winter growing seasons had a total rainfall of $627,705,368$ and $165 \mathrm{~mm}$, respectively (Figure 1), and average temperatures of $26,27,25$ and $22{ }^{\circ} \mathrm{C}$, respectively (Figure 1), while mean global radiation for the seasons was 20, 21, 17 and $15 \mathrm{MJ} / \mathrm{m}^{2} / \mathrm{d}$.

There were no significant interactions between fertilizer sources and $\mathrm{N}$ rates in terms of DMY or chemical composition, so the main effects only are presented. Annual dry matter yield of the nonfertilized treatment with $\mathrm{N}$ fertilizer was $31.3 \mathrm{t}$ $\mathrm{DM} / \mathrm{ha}$. In general, increasing $\mathrm{N}$ rates significantly increased seasonal and annual DMY by up to $30 \%$ from applying $1,800 \mathrm{~kg} \mathrm{~N} / \mathrm{ha} /$ year (150 kg N/ha/cut) compared with non-fertilized treatment. According to the quadratic response function, the maximum DMY point was reached with approximately $159 \mathrm{~kg}$ $\mathrm{N} /$ ha/cut, equivalent to $477 \mathrm{~kg} \mathrm{~N} /$ ha/year; Table 1). Yield responses were similar for both urea and ammonium nitrate in all seasons. Seasonal yields per day followed the following order: summer $(1,243)>$ autumn $(1,086)>$ spring $(768)>$ winter (378 kg/ha/day).

The results obtained should indicate the likely responses to $\mathrm{N}$ fertilizer of this grass in this environment. Unfortunately, lack of resources did not allow us to study $\mathrm{N}$ losses into the environment from these fertilizers, especially at the higher application rates, to assess leaching losses and in particular the possible release of additional greenhouse gases into the atmosphere. Since recovery rates for applied $\mathrm{N}$ in plant material ranged from 8.3 to $30.6 \%$ for varying combinations of $\mathrm{N}$ applied and growing season, and 8.1 to $31.1 \%$ for combinations of different $\mathrm{N}$ sources and growing season, a large percentage of the applied $\mathrm{N}$ is unaccounted.

While this study has demonstrated positive responses in dry matter yield of Mombasa guinea grass to $\mathrm{N}$ fertilizer, these increases (about 30\%) were much lower than those reported in Thailand by Hare et al. (2015) (100\% increase with 40-60 kg $\mathrm{N} /$ ha every 40-45 days). The low responses in our study may reflect the high dry matter yield obtained in the absence of added fertilizer (31,305 kg DM/ ha/year). Yields of this magnitude in the absence of fertilizer are quite unusual and indicate high inherent fertility of the soil. We achieved more than $90 \%$ of these potential yields without adding $\mathrm{N}$ fertilizer. The soil had adequate base saturation, and $\mathrm{pH}$ and a relatively high organic matter content for tropical soils $\left(25 \mathrm{~g} / \mathrm{dm}^{3}\right)$ and climatic conditions were relatively satisfactory for the proper development of this grass, especially during summer and autumn. 
Table 1. Effects of type and level of nitrogen fertilizer on dry

matter yields of Mombasa guinea grass by season of the year.

\begin{tabular}{|c|c|c|c|c|c|c|}
\hline & Summer & Autumn & Winter & Spring & Total & Mean per harvest \\
\hline $\mathrm{N}$ rate $(\mathrm{kg} \mathrm{N} / \mathrm{ha} /$ cut $)$ & \multicolumn{5}{|c|}{ DMY (kg/ha) } & \\
\hline 0 & $10,488^{(1)}$ & $9,638^{(2)}$ & $3,795^{(3)}$ & $7,385^{(4)}$ & $31,305^{(5)}$ & 2,609 \\
\hline 50 & 12,188 & 9,300 & 4,595 & 8,420 & 34,503 & 2,875 \\
\hline 100 & 12,340 & 10,343 & 4,920 & 9,595 & 37,198 & 3,100 \\
\hline 150 & 13,330 & 12,508 & 4,890 & 9,628 & 40,355 & 3,361 \\
\hline 200 & 13,315 & 11,405 & 5,220 & 9,135 & 39,075 & 3,256 \\
\hline Mean & 12,332 & 10,639 & 4,684 & 8,833 & 36,487 & 3,040 \\
\hline C.V. $(\%)$ & 12.8 & 17.8 & 21.1 & 15.9 & 9.1 & \\
\hline \multicolumn{7}{|l|}{$\mathrm{N}$ sources } \\
\hline Urea & 12,170 & 10,538 & 4,556 & 8,824 & 36,088 & \\
\hline $\mathrm{AN}^{*}$ & 12,494 & 10,739 & 4,812 & 8,841 & 36,886 & \\
\hline $\operatorname{LSD}(5 \%)$ & 1,023 & 1,226 & 641 & 911 & 2,148 & \\
\hline
\end{tabular}

$* \mathrm{AN}=$ ammonium nitrate.

(1) $\hat{\mathrm{Y}}=10,972+4.53 \mathrm{x}\left(\mathrm{R}^{2}=0.86^{* *}\right) ;{ }^{(2)} \hat{\mathrm{Y}}=9,290+4.50 \mathrm{x}\left(\mathrm{R}^{2}=0.65^{*}\right) ;{ }^{(3)} \hat{\mathrm{Y}}=4,055+2.10 \mathrm{x}\left(\mathrm{R}^{2}=0.84^{* *}\right) ;{ }^{\text {(4) }} \hat{\mathrm{Y}}$ $=7,291+11.13 \mathrm{x}-0.01 \mathrm{x}^{2}\left(\mathrm{R}^{2}=0.97 * *\right) ;{ }^{(5)} \hat{\mathrm{Y}}=30,995+7.61 \mathrm{x}-0.002 \mathrm{x}^{2}\left(\mathrm{R}^{2}=0.96^{* *}\right)$; (point of maximum) $\mathrm{PM}$ $=1903 \mathrm{~kg} \mathrm{~N} / \mathrm{ha}, 159 \mathrm{~kg} / \mathrm{ha} /$ cut and $477 \mathrm{~kg} / \mathrm{ha} /$ season; and (economical dose) $\mathrm{ED}=1,383 \mathrm{~kg} / \mathrm{ha}, 115 \mathrm{~kg} / \mathrm{ha} / \mathrm{cut}$ and $345 \mathrm{~kg} / \mathrm{ha} /$ season).

Fernandes et al. (2015) suggested that, depending on soil type and management of the area, the soil may supply the $\mathrm{N}$ requirements of forage grasses, reaching good production levels without added fertilizer. Although we achieved high DM yields without adding $\mathrm{N}$ fertilizer, responses from added $\mathrm{N}$ were still substantial with the optimal economic rate of urea application being approximately $115 \mathrm{~kg} \mathrm{~N} / \mathrm{ha} / \mathrm{cut}$ or $346 \mathrm{~kg}$ $\mathrm{N} / \mathrm{ha} /$ year. For these calculations we used a urea price of $\mathrm{R} \$ 1,780.00$ per tons, equivalent to $\mathrm{U} \$$ 539.39, approximately, feed conversion values in $\mathrm{kg}$ of DM intake / $\mathrm{kg} \mathrm{LWG}$ (weight gain) = 9, i.e. it would be necessary to eat $9.0 \mathrm{~kg} \mathrm{DM}$ to gain $1.0 \mathrm{~kg}$ of live weight, with animals showing live weight initial 13@ and the expected weight gain close to $1.0 \mathrm{~kg}$ per day (adapted from the study of Coan et al. 2008 and Difante et al. 2010) and the price of @= R $\$ 133.00$, being the mean values of the last three years (IEA 2016). In this way, the received value per $\mathrm{kg}$ of DM is $\mathrm{R} \$ 0.99$.

Tropical grasses, such as Mombasa guinea grass, can produce very high seasonal forage surplus, as observed in this study, with the average DMY in summer and autumn more than double winter production and 30\% more than spring production. These seasonal surpluses could either be made into silage for feeding in winter and spring or fenced off to provide standing hay for feeding in the months of forage shortage (Galindo et al. 2018).

The absence of differences in responses in DMY to urea and ammonium nitrate application supports findings from other studies with Mombasa guinea grass (Fernandes et al. 2015) and Tanzania guinea grass (Silveira et al. 2015). In contrast, Costa et al. (2010), studying $\mathrm{N}$ fertilization of Marandu palisade grass (Urochloa brizantha $\mathrm{cv}$. Marandu) found that ammonium sulfate promoted higher DMY than urea, regardless of the $\mathrm{N}$ rates, in all years of the study, but a response to sulfur may have been implicated.

Pastures are considered the basic forage for beef cattle in Brazil since they are a less costly method to produce animal protein for human consumption (Fernandes et al. 2015) with climatic conditions favoring the production of fodder in many locations for much of the year. However, forage plants are usually not fertilized and over time pasture decline occurs with reduction in both quality and quantity of forage (Silveira et al. 2015). Most Brazilian pastures show some degradation degree, as and little technology is adopted, especially in the Cerrado region, where approximately $40 \%$ of the Brazilian livestock population is concentrated (Dupas et al., 2016; Galindo et al. 2018). The use of pasture fertilization practices has resulted in higher performance indices 
as a result of higher forage supply, both in quantity and quality (Silva et al. 2013).

Increasing $\mathrm{N}$ rates significantly increased $\mathrm{CP}$ concentrations in harvested forage, particularly when rates of $150 \mathrm{~kg} \mathrm{~N} / \mathrm{ha}$ were applied after each harvest (Table 2). There were no further increases in CP concentration when $200 \mathrm{~kg} \mathrm{~N} / \mathrm{ha}$ was applied after each cut. While ammonium nitrate produced higher CP concentrations than urea in all seasons, differences were significant only in winter (Table 2).

Table 2. Effects of type and level of nitrogen fertilizer on crude protein concentration (CP), concentrations of neutral detergent fiber (NDF) and acid detergent fiber (ADF), lignin, cellulose and hemicellulose of Mombasa guinea grass by season of the year.

\begin{tabular}{|c|c|c|c|c|c|c|c|c|}
\hline & Summer & Autumn & Winter & Spring & Summer & Autumn & Winter & Spring \\
\hline $\mathrm{N}$ rate $(\mathrm{kg} \mathrm{N} / \mathrm{ha} /$ cut $)$ & $\% \mathrm{CP}$ & & & & $\% \mathrm{NDF}$ & & & \\
\hline 0 & $9.5^{(1)}$ & $10.1^{(2)}$ & $12.1^{(3)}$ & $9.2^{(4)}$ & $70.6^{(5)}$ & $69.5^{(6)}$ & $68.2^{(7)}$ & 68.2 \\
\hline 50 & 10.1 & 10.9 & 13.5 & 9.8 & 71.1 & 68.0 & 67.2 & 68.0 \\
\hline 100 & 10.5 & 11.1 & 14.7 & 10.0 & 70.7 & 68.7 & 66.6 & 68.4 \\
\hline 150 & 13.1 & 12.7 & 15.5 & 12.4 & 66.7 & 67.0 & 64.4 & 68.0 \\
\hline 200 & 13.7 & 12.3 & 15.7 & 13.4 & 68.6 & 67.2 & 66.7 & 69.0 \\
\hline Mean & 11.4 & 11.4 & 14.3 & 11.0 & 69.5 & 68.1 & 66.6 & 68.3 \\
\hline $\mathrm{CV}(\%)$ & 6.5 & 14.2 & 5.4 & 12.7 & 2.2 & 1.7 & 1.5 & 3.1 \\
\hline \multicolumn{9}{|l|}{$\mathrm{N}$ sources } \\
\hline Urea & $11.2 \mathrm{a}$ & $11.0 \mathrm{a}$ & $13.8 \mathrm{~b}$ & $10.6 \mathrm{a}$ & $70.0 \mathrm{a}$ & $68.0 \mathrm{a}$ & $67.3 \mathrm{~b}$ & $68.4 \mathrm{a}$ \\
\hline $\mathrm{AN}^{*}$ & $11.6 \mathrm{a}$ & $11.8 \mathrm{a}$ & $14.8 \mathrm{a}$ & $11.3 \mathrm{a}$ & $69.1 \mathrm{a}$ & $68.2 \mathrm{a}$ & $65.9 \mathrm{a}$ & $68.2 \mathrm{a}$ \\
\hline \multirow[t]{2}{*}{ L.S.D. $(5 \%)$} & 0.75 & 1.64 & 0.78 & 1.40 & 1.5 & 1.2 & 1.0 & 2.1 \\
\hline & Summer & Autumn & Winter & Spring & Summer & Autumn & Winter & Spring \\
\hline $\mathrm{N}$ rate $(\mathrm{kg} \mathrm{N} / \mathrm{ha} / \mathrm{cut})$ & \multicolumn{4}{|c|}{$\% \mathrm{ADF}$} & \multicolumn{4}{|c|}{$\%$ Lignin } \\
\hline 0 & 39.8 & 38.0 & 34.8 & 38.4 & 4.7 & 4.00 & 4.0 & 4.8 \\
\hline 50 & 40.8 & 36.9 & 34.3 & 38.8 & 4.5 & 4.05 & 3.7 & 4.9 \\
\hline 100 & 40.3 & 37.1 & 34.6 & 39.3 & 5.0 & 4.05 & 4.4 & 4.8 \\
\hline 150 & 36.8 & 36.0 & 32.4 & 38.5 & 4.8 & 4.40 & 4.0 & 5.2 \\
\hline 200 & 39.1 & 37.1 & 34.5 & 38.4 & 4.3 & 5.13 & 4.6 & 5.4 \\
\hline Mean & 39.4 & 37.0 & 34.1 & 38.7 & 4.6 & 4.33 & 4.1 & 5.0 \\
\hline $\mathrm{CV}(\%)$ & 4.6 & 2.9 & 5.5 & 4.9 & 15.1 & 22.2 & 16.6 & 12.5 \\
\hline \multicolumn{9}{|l|}{$\mathrm{N}$ sources } \\
\hline Urea & $39.4 \mathrm{a}$ & $36.8 \mathrm{a}$ & $34.1 \mathrm{a}$ & $38.2 \mathrm{a}$ & 4.9 & 4.2 & 3.9 & 5.1 \\
\hline $\mathrm{AN}^{*}$ & $39.4 \mathrm{a}$ & $37.3 \mathrm{a}$ & $34.2 \mathrm{a}$ & $39.1 \mathrm{a}$ & 4.4 & 4.4 & 4.3 & 4.8 \\
\hline \multirow[t]{2}{*}{ L.S.D. $(5 \%)$} & 1.8 & 1.1 & 1.9 & 1.9 & 0.7 & 1.0 & 0.7 & 0.6 \\
\hline & Summer & Autumn & Winter & Spring & Summer & Autumn & Winter & Spring \\
\hline $\mathrm{N}$ rate $(\mathrm{kg} \mathrm{N} / \mathrm{ha} /$ cut $)$ & \multicolumn{4}{|c|}{$\%$ Cellulose } & \multicolumn{4}{|c|}{$\%$ Hemicellulose } \\
\hline 0 & 33.5 & 31.9 & 28.3 & 31.8 & 30.8 & 31.5 & 33.4 & 29.7 \\
\hline 50 & 33.5 & 30.9 & 28.6 & 30.6 & 30.3 & 31.1 & 32.9 & 29.2 \\
\hline 100 & 32.6 & 30.7 & 25.3 & 32.0 & 30.4 & 31.6 & 32.0 & 29.1 \\
\hline 150 & 30.2 & 29.1 & 26.3 & 31.5 & 29.8 & 31.0 & 32.1 & 29.6 \\
\hline 200 & 32.1 & 29.7 & 27.2 & 30.6 & 29.5 & 30.1 & 32.2 & 30.6 \\
\hline Mean & 32.4 & 30.5 & 27.1 & 31.3 & 30.2 & 31.1 & 32.5 & 29.7 \\
\hline C.V. $(\%)$ & 4.5 & 6.7 & 9.1 & 4.4 & 5.3 & 2.7 & 4.8 & 4.8 \\
\hline \multicolumn{9}{|l|}{$\mathrm{N}$ sources } \\
\hline Urea & 32.7 & 30.2 & 27.3 & 30.9 & 30.6 & 31.2 & 33.2 & 30.2 \\
\hline $\mathrm{AN}^{*}$ & 32.1 & 30.8 & 27.0 & 31.7 & 29.7 & 30.9 & 31.8 & 20.1 \\
\hline L.S.D. (5\%) & 1.5 & 2.1 & 2.5 & 1.4 & 1.61 & 0.85 & 1.57 & 1.43 \\
\hline
\end{tabular}

Means followed by the same letters within columns do not differ by Tukey's test at $5 \%$ probability. *AN $=$ ammonium nitrate. (1) $\hat{\mathrm{Y}}=9.1+0.02 \mathrm{x}\left(\mathrm{R}^{2}=0.92^{* *}\right) ;{ }^{(2)} \hat{\mathrm{Y}}=10.2+0.01 \mathrm{x}\left(\mathrm{R}^{2}=0.86^{* *}\right) ;{ }^{(3)} \hat{\mathrm{Y}}=12.5+0.02 \mathrm{x}\left(\mathrm{R}^{2}=0.93^{* *}\right) ;$ (4) $\hat{\mathrm{Y}}=8.8+0.02 \mathrm{x}\left(\mathrm{R}^{2}=\right.$ $\left.0.91^{* *}\right) ;{ }^{(5)} \hat{\mathrm{Y}}=71.2-0.02 \mathrm{x}\left(\mathrm{R}^{2}=0.51 *\right) ;{ }^{(6)} \hat{\mathrm{Y}}=69.2-0.01 \mathrm{x}\left(\mathrm{R}^{2}=0.71 * *\right) ;{ }^{(7)} \hat{\mathrm{Y}}=68.5-0.04 \mathrm{x}+0.0001 \mathrm{x}^{2}\left(\mathrm{R}^{2}=0.66^{*}\right)$. 
The fact that $\mathrm{CP}$ concentrations in forage produced remained above $9 \%$, even in the absence of $\mathrm{N}$ fertilizer application, is further evidence of the inherent fertility of these soils. It is therefore not surprising that $\mathrm{CP}$ levels in our study increased linearly with increasing $\mathrm{N}$ rates since responses in DM yield were much lower than in other studies. Similar results were obtained by Viana et al. (2011), when increasing $\mathrm{N}$ rates resulted in linear increases in $\mathrm{CP}$ concentrations in signal grass (U. decumbens).

The CP levels lower than $7 \%$ reduce the digestion rate of forages, due to inadequate $\mathrm{N}$ levels to maintain the population of rumen microorganisms resulting in slower digestion rates and rate of ingesta passage and reduction in dry matter intake (Van Soest 1994). The CP concentrations in this study were well above $7 \%$, even in control treatments, so the forage should provide at least maintenance diets for ruminants, without making allowance for the ability of animals to select a higher quality diet than the mean of the available forage.

The marked seasonal differences in pasture growth would largely be a function of differences in rainfall since winter rainfall was much lower than that in the other seasons, with reduced growth being impaired by lower temperatures and global radiation in winter as guinea grass is quite sensitive to cool conditions.

The NDF concentrations decreased in summer, autumn and winter, but not in spring, with increasing rates of $\mathrm{N}$, and there was no effect of fertilizer source except in winter when ammonium nitrate produced lower concentrations than urea (Table 2). Lignin, cellulose and hemicellulose concentrations were not affected by $\mathrm{N}$ rates or $\mathrm{N}$ fertilizer type (Tables 2 and 5).

In his review, Van Soest (1994) stated that NDF level in bulky forages was the factor most limiting consumption, and cell wall concentrations in DM greater than $55-60 \%$ were negatively correlated with intake of forage. Since most fibrous $\mathrm{C}_{4}$ tropical forages have NDF concentrations more than $60 \%$, intakes of these forages are often limited. Also, Martuscello et al. (2015) demonstrated that increasing $\mathrm{N}$ rates could increase the stem: leaf ratio, thereby increasing fiber concentration. Since NDF concentrations in forage exceeded $60 \%$ throughout the year regardless of $\mathrm{N}$ fertilizer applications, forage intake by animals would have been limited, as it is for tropical grasses in general.

In our current study, the ADF levels were not influenced by $\mathrm{N}$ fertilizer application. In contrast, Benett et al. (2008) reported decreases in ADF concentrations in Marandu palisade grass with increasing rates of $\mathrm{N}$ fertilizer. On the other hand, Mistura et al. (2007) found that leaf ADF concentrations increased linearly in Pennisetum purpureum with increasing rates of $\mathrm{N}$ application, which reflected changes in the structural components of the plant with accelerated maturity and increases in stem components increasing the fiber content of the plant material.

Lignin values ranged from $4.11 \%$ in winter to $4.98 \%$ in spring and were much lower than the values found in $P$. purpureum $(11.5 \%)$ and Colonião guinea grass (9.3\%) (Savioli et al. 2000). The values for cellulose ranged from $27.1 \%$ in winter to $32.4 \%$ in summer, and hemicellulose values ranged from $29.7 \%$ in spring to $32.5 \%$ in winter. The lower the fiber content, the better the digestibility and nutritional quality of the food, since fibrous foods are a mechanical barrier to the attack of microorganisms on substrates in the rumen (Oliveira et al. 2017).

In general, higher digestibility values are observed during autumn and winter than in spring and summer, with the rate of decline in digestibility with the developmental advance (stem elongation and flowering) being accelerated with higher temperatures (Macadam et al. 1996). Although lignin, cellulose and hemicellulose concentrations varied little with the season, values for lignin and cellulose were lower in the colder periods than in the warmer seasons. However, rates of $\mathrm{N}$ fertilizer did not influence the lignification of the cell wall of Mombasa guinea grass.

\section{Conclusions}

The study has shown positive responses in Mombasa guinea grass to increasing rates of $\mathrm{N}$ fertilizer application with increases in dry matter yield and improvement in quality, i.e., increases in $\mathrm{CP}$ concentration, reduction in NDF concentration and no effects on ADF, lignin, cellulose and hemicellulose concentrations. The absence of any differences in responses from urea and ammonium nitrate suggests that urea would be the best choice of fertilizer because of the lower cost per unit of $\mathrm{N}$, if $\mathrm{N}$ is applied at all given the excellent DM yield and satisfactory $\mathrm{CP}$ concentration without added $\mathrm{N}$. The high dry matter production from these soils in the non-fertilized treatment with $\mathrm{N}$ fertilizer 
(31.3 $\mathrm{t} \mathrm{DM} / \mathrm{ha}$ ) and the $\mathrm{CP}$ concentrations in forage produced (9.2-12.1\%). Thus, rates of $\mathrm{N}$ fertilizer application above $115 \mathrm{~kg} \mathrm{~N} / \mathrm{ha} / \mathrm{cut}$ could not be justified by DM yield responses. Further study is needed to clarify the optimal season to apply $\mathrm{N}$ fertilizer when resources are limited. Longer-term studies are needed to confirm these findings and to measure losses of $\mathrm{N}$ to the atmosphere, especially at the high $\mathrm{N}$ fertilizer rates to determine the effects on the release of greenhouse gases.

\section{Literature Cited}

Benett, C.G.S.; Buzetti, S.; Silva, K.S.; Bergamaschine, A.F.; Fabricio, J.A.

2008. Yield and bromatologic composition of Marandu grass as function of sources and doses of nitrogen. Ciência e Agrotecnologia, 32: 1629-1636.

Casali, A.O.; Detmann, E.; Valadares Filho, S.C.; Pereira, J.C.;

Cunha, M.; Detmann, K.S.C.; Paulino, M.F.

2009. Estimation of fibrous compounds contents in ruminant feeds with bags made from different textiles. Revista Brasileira de Zootecnia, 38: 130-138.

Coan, R.M.; Reis, R.A.; Resende, F.D.D.; Sampaio, R.L.;

Schocken-Iturrino, R.P.; Garcia, G.R.; Berchielli, T.T.

2008. Economical viability, performance, and carcass characteristics of confined steers fed Palisade grass silage, Tanzania grass silage or corn silage. Revista Brasileira de Zootecnia, 37: 311-318 (In Portuguese, abstract in English).

Costa, K.A.P.; Faquin, V.; Oliveira, I.P.

2010. Nitrogen doses and sources on pasture recuperation of grass marandu. Arquivo Brasileiro de Medicina Veterinária e Zootecnia, 62: 192-199.

Difante, G.D.S.; Euclides, V.P.B.; Nascimento Júnior, D.D.;

Silva, S.C.D.; Barbosa, R.A.; Torres Júnior, R.A.D.A.

2010. Performance and feed conversion of beef cattle steers on Tanzania guineagrass under two grazing intensities and rotational stocking. Revista Brasileira de Zootecnia, 39: 33-41.

Dupas, E.; Buzetti, S.; Rabêlo, F.H.S.; Sarto, A.L.; Cheng, N.C.;

Teixeira Filho, M.C.M.; Galindo, F.S.; Dinalli, R.P.; Gazola, R.N. 2016. Nitrogen recovery, use efficiency, dry matter yield, and chemical composition of palisade grass fertilized with nitrogen sources in the Cerrado biome. Australian Journal of Crop Science, 10: 1330-1338.

Empresa Brasileira de Pesquisa Agropecuária.

2013. National Soil Research Center. Brazilian system of soil classification. 3rd Edn. DF Embrapa. Brasília, Brazil. 353 p.

Fernandes, J.C.; Buzetti, S.; Dupas, E.; Teixeira Filho, M.C.M.; Andreotti, M.

2015. Sources and rates of nitrogen fertilizer used in Mombasa guineagrass in the Brazilian Cerrado region. African Journal of Agricultural Research, 10: 2076-2082.

Ferreira, D.F.

2011. Sisvar: a computer statistical analysis system. Ciência e Agrotecnologia, 35: 1039-1042.

Galindo, F.S.; Beloni, T.; Buzetti, S.; Teixeira Filho, M.C.M.;

Dupas, E.; Ludkiewicz, M.G.Z.

2018. Technical and economic viability and nutritional quality of mombasa guinea grass silage production. Acta Scientiarum. Agronomy, 40: e36395.

Galindo, F.S.; Buzetti, S.; Teixeira Filho, M.C.M.; Dupas, E.; Ludkiewicz, M.G.Z.

2017. Application of different nitrogen doses to increase nitrogen efficiency in Mombasa guinegrass (Panicum maximum cv. mombasa) at dry and rainy seasons. Australian Journal of Crop Science, 11: 1657-1664.

Hare, M.D.; Pizarro, E.A.; Phengphet, S.; Songsiri, T.; Sutin, N. 2015. Evaluation of new hybrid brachiaria lines in Thailand.

1. Forage production and quality. Tropical GrasslandsForrajes Tropicales, 3: 83-93.

Instituto de economia agrícola - IEA.

Data base. Disponible in: < http://www.iea.sp.gov.br/out/ bancodedados.html> Acess: 09 apr. 2018.

Macadam, J.W.; Kerley, M.S.; Piwonka, E.J.

1996. Tiller development influences seasonal change in cell wall digestibility of big bluestem (Andropogon gerardii). Journal of the Science of Food and Agriculture, 70: 79-88.

Martuscello, J.A.; Silva, L.P.; Cunha, D.N.F.V.; Batista, A.C.S.; Braz, T.G.S.; Ferreira, P.S.

2015. Nitrogen fertilization in massaigrass: production and morphogenesis. Ciência Animal Brasileira, 16: 1-13.

Mistura, C.; Fonseca, D.M.; Moreira, L.M.; Fagundes, J.L.;

Morais, R.V.; Queiroz, A.C.; Ribeiro Júnior, J.I.

2007. Effect of nitrogen fertilization and irrigation on the chemical composition of the leaf blade and whole plant of elephantgrass under grazing. Revista Brasileira de Zootecnia, 36: 1707-1714.

Oliveira, V.S.; Morais, J.A.S.; Muniz, E.N.; Fagundes, J.L.;

Lima, I.G.S.; Santana, J.S.; Santos, C.B.

2017. Ruminal kinetics of tropical forages submitted or not to irrigation. Boletim de Indústria Animal, 74: 195-204.

Savioli, N.M.F. de; Fukushima, R.S.; Lima, C.G.; Gomide, C.A. 2000. Yield and spectrophotometric pattern of lignin extracted from cell wall, neutral detergent fiber or acid detergent fiber. Revista Brasileira de Zootecnia, 29: 988-996.

Silva, D.R.G.; Costa, K.A.P.; Faquin, V.; Oliveira, I.P.; Bernardes, T.F.

2013. Rates and sources of nitrogen in the recovery of the structural and productive characteristics of marandu grass. Revista Ciência Agronômica, 44: 184-191.

Silveira, M.L.; Vendramini, J.M.B.; Sellers, B.; Monteiro, F.A.; Artur, A.G.; Dupas, E.

2015. Bahiagrass response and $\mathrm{N}$ loss from selected $\mathrm{N}$ fertilized sources. Grass and Forage Science, 70: 154-160.

Van Soest, P.J.

1994. Nutritional ecology of the ruminant. 2nd Edn. Cornell University. Ithaca, NY,US. 476 p.

Viana, M.C.M.; Freire, F.M.; Ferreira, J.J.; Macêdo, G.A.R.; Cantarutti, R.B.; Mascarenhas, M.H.T.

2011. Nitrogen fertilization on yield and chemical composition of signalgrass under rotational grazing. Revista Brasileira de Zootecnia, 40: 1497-1503. 
